\title{
HUBUNGAN PENGETAHUAN IBU HAMIL TENTANG KENAIKAN BERAT BADAN SELAMA HAMIL DENGAN SIKAP IBU DALAM PEMENUHAN GIZI SEIMBANG
}

Lely Khulafa'ur Rosidah, S.ST.M.Kes ${ }^{1}$, Al-Maida Dianty Nuratika ${ }^{2}$

Akademi Kebidanan Dharma Husada Kediri Jawa timur

\begin{abstract}
ABTRAK
Kenaikan berat badan pada wanita ketika hamil merupakan hal yang wajar. Kenaikan berat badan yang ideal selama kehamilan setiap orang berbeda-beda, tergantung pada berat badan sebelum hamil. Penelitian ini bertujuan untuk mengetahui hubungan pengetahuan ibu hamil tentang kenaikan berat badan selama hamil dengan sikap ibu dalam pemenuhan gizi seimbang.

Penelitian ini menggunakan rancangan korelasional dengan pendekatan cross sectional. Populasinya adalah semua ibu hamil di Kelurahan Ngronggo Kecamatan Kota, Kota Kediri sejumlah 55 responden. Pengambilan sampling menggunakan teknik purposive sampling didapatkanln sampel 35 responden. Variabel independent yaitu pengetahuan ibu tentang kenaikan berat badan selama hamil dan variabel dependent yaitu sikap ibu dalam pemenuhan gizi seimbang. Instrumen penelitian menggunakan kuesioner. Pengolahan data dengan menggunakan editing, coding, scoring, dan tabulating. Kemudian dianalisa dengan uji statistik chi kuadrat dengan taraf signifikan 5\%.

Hasil penelitian dari 35 responden didapatkan sebagian besar dari respoden 14 responden $(40 \%)$ yang berpengetahuan baik. Sebagian besar responden $22(62,86 \%)$ bersikap negatif. Berdasarkan hasil uji chi kuadrat didapatkan $x^{2}$ hitung 18,87 dan bila dibandingkan dengan $x^{2}$ tabel $(\alpha=0,05)$ adalah 5,991 maka $x^{2}$ hitung $>x^{2}$ tabel yaitu $18,87>5,991$ sehingga $\mathrm{H}_{1}$ diterima artinya ada hubungan antara pengetahuan ibu hamil tentang kenaikan berat badan selama hamil dengan sikap ibu dalam pemenuhan gizi seimbang .

Berdasarkan hasil penelitian, hendaknya informasi tentang kenaikan berat badan selama hamil lebih di tingkatkan sehingga ibu hamil mampu memenuhi kebutuhan gizinya dengan baik. Dari pengetahuan yang baik akan menjadi dasar ibu hamil untuk bersikap dalam pemenuhan gizi seimbang.
\end{abstract}

\section{Kata Kunci : Pengetahuan, Kenaikan Berat Badan Selama Hamil, Sikap, Pemenuhan Gizi Seimbang.}




\section{PENDAHULUAN}

Kehamilan adalah hasil pembuahan (konsepsi) yang terjadi didalam rahim wanita sampai menjelang kelahiran bayinya. Selama didalam rahim ibu disebut janin. Sejak terjadinya konsepsi sampai menjelang lahir janin mengalami proses pertumbuhan dan perkembangan (Boediman, 2009 :31).

Kehamilan adalah suatu keadaan yang istimewa bagi seorang wanita sebagai calon ibu karena pada masa kehamilan akan terjadi perubahan fisik yang mempengaruhi kehidupannya. Pola makan dan gaya hidup sehat dapat membantu pertumbuhan dan perkembangan janin dalam rahim ibu. Pada waktu terjadi kehamilan akan terjadi banyak perubahan baik perubahan fisik, sosial maupun mental. Walaupun demikian para calon ibu harus tetap berada didalam keadaan sehat optimal karena disini seorang ibu tidak hidup dengan sendiri tetapi dia hidup bersama dengan janin yang dikandung. Oleh karena itu, para calon ibu harus memiliki gizi yang cukup sebelum hamil dan lebih lagi ketika hamil. Ibu yang hamil harus memiliki gizi yang cukup karena gizi yang didapat akan digunakan untuk dirinya sendiri dan juga janinnya (Kristiyanasari, 2010 : 43).

Pada umumnya masih banyak masyarakat yang percaya tentang mitosmitos kehamilan baik sadar atau tidak disadari. Pantangan makanan selama hamil merupakan salah satu mitos yang sudah diyakini secara turun temurun Kristiyanasari, $2010: 43$ ).

Kenaikan berat badan pada wanita ketika hamil merupakan hal yang wajar.(Novia 2013). Kenaikan berat badan yang ideal selama kehamilan setiap orang berbeda-beda, tergantung pada berat badan sebelum hamil. Jika sebelum hamil berat badan ibu dibawah normal (Kurus), pada trimester awal idealnya naik $2,25 \mathrm{~kg}$. Selanjutnya, berat badan akan terus naik minimum 450 gram perminggunya. Dengan demikian, total kenaikkan berat badan selama kehamilan 13-18 kg (Wibisono, 2008 : 66)

Berat badan ibu selama hamil dan kenaikan berat badan ibu selama hamil kurang (underweight) atau lebih (overweight) dari normal akan membuat kehamilan menjadi resiko (lowris). Berat badan ibu yang kurang akan beresiko melahirkan berat badan kurang atau berat bayi lahir rendah (BBLR) (Waryana, 2010).

Kekurangan Energi Kronis (KEK) pada ibu hamil ditandai dengan Lingkar Lengan atas $<23,5 \mathrm{~cm}$ dan merupakan salah satu masalah gizi nasional yang selalu mendapat prioritas atau perhatian karena prevalensinya masih tinggi dan bahkan mengakibatkan tinginya kematian neonatal maupun kematian ibu. Menurut data WHO (2011).

Angka kematian ibu (AKI) di Indonesia adalah yang tertinggi bila dibandingkan dengan negara-negara ASEAN lainnya. Menurut data pencapaian AKI Indonesia berdasarkan hasil analisis survei Demografi Kesehatan Indonesia (SDKI) 2007 di Indonesia adalah 228/100.000 kelahiran hidup. Adapun penyebab kematian ibu langsung adalah perdarahan, keracunan kehamilan yang disertai kejang, aborsi, dan infeksi (Depkes, 2007).

\section{METODE}

Pada penelitian ini desain penelitian yang digunakan adalah studi korelasi dengan pendekatan Cross Sectional. Semua ibu hamil di Kelurahan Ngronggo Kecamatan Kota, Kota Kediri sejumlah 55 responden

Variabel independen penelitian ini adalah Pengetahuan ibu tentang kenaikan berat badan selama hamil. Variabel dependen dalam penelitian ini adalah Sikap ibu dalam pemenuhan gizi seimbang 
Instrumen yang digunakan dalam penelitian ini adalah kuesioner. Kuesioner pengetahuan ibu hamil tentang kenaikan berat badan selama hamil sejumlah 15 soal dan Kuesioner sikap ibu dalam pemenuhan gizi seimbang ibu hamil sejumlah 14 soal. Hasil penelitian kuesioner yang telah dikumpukan lalu diolah dengan cara editing, coding, scoring, dan tabulating untuk pengujian hipotesa, kemudian dianalisa dengan Uji Chi kuadrat atau $\chi^{2}$.

\section{HASIL}

Data Khusus

a. Pengetahuan Ibu Hamil Tentang Kenaikan Berat Badan.

Tabel IV.6 Distribusi Frekuensi Pengetahuan Ibu Hamil Tentang Kenaikan Berat Badan Selama Hamil di Kelurahan Ngronggo Kecamatan Kota, Kota Kediri.

\begin{tabular}{clccc}
$\mathrm{N}$ & & Pengetahuan & Frekuensi & Prosentase (\%) \\
$\mathrm{o}$ & & & \\
\hline 1 & Baik & 14 & 40 \\
\hline 2 & Cukup & 13 & 37,1 \\
\hline 3 & Kurang & 8 & 22,8 \\
\hline & Total & 35 & 100
\end{tabular}

Hasil penelitian pada tabel IV.7 didapat dari total 35 responden sebagian besar dari responden yaitu $14(40 \%)$ mempunyai pengetahuan baik tentang kenaikan berat badan selama hamil.

b. Sikap ibu dalam pemenuhan gizi seimbang di Kelurahan Ngronggo Kecamatan Kota, Kota Kediri.

Tabel IV.7 Distribusi Frekuensi Sikap Ibu dalam pemenuhan gizi seimbang di Kelurahan Ngronggo Kecamatan Kota, Kota Kediri

\begin{tabular}{clccc} 
No & & Sikap & Frekuensi & Prosentase $(\%)$ \\
\hline 1 & Positif & 13 & 37,14 \\
\hline 2 & Negatif & 22 & 62,86 \\
\hline & Total & 35 & 100
\end{tabular}

Hasil penelitian pada tabel IV.8 didapat dari total 35 responden sebagian besar dari responden yaitu 22 responden $(62,86 \%)$ bersikap negatif dalam pemenuhan gizi seimbang. 
Hubungan pengetahuan ibu hamil tentang kenaikan berat badan selama hamil dengan sikap ibu dalam pemenuhan gizi seimbang

Tabel IV.8 Tabel silang hubungan pengetahuan ibu hamil tentang kenaikan berat badan selama hamil dengan sikap ibu dalam pemenuhan gizi seimbang di Kelurahan Ngronggo Kecamatan Kota, Kota Kediri.

\begin{tabular}{|c|c|c|c|c|c|c|}
\hline \multirow{3}{*}{ Pengetahuan } & \multicolumn{4}{|c|}{ Sikap } & \multirow{2}{*}{\multicolumn{2}{|c|}{ Total }} \\
\hline & \multicolumn{2}{|c|}{ Positif } & \multicolumn{2}{|c|}{ Negatif } & & \\
\hline & Jumlah & $\%$ & Jumlah & $\%$ & Jumlah & $\%$ \\
\hline Baik & 7 & 20 & 7 & 20 & 14 & 40 \\
\hline Cukup & 6 & 17 & 7 & 20 & 13 & 37 \\
\hline Kurang & 0 & 0 & 8 & 23 & 8 & 23 \\
\hline Total & 13 & 37 & 22 & 63 & 35 & 100 \\
\hline & $x^{2}$ hitung & 8,87 & $x^{2}$ tat & $=5$, & & \\
\hline
\end{tabular}

Keterangan : Menunjukkan terdapat hubungan $\left(x^{2}\right.$ hitung $>x^{2}$ tabel)

Berdasarkan hasil penelitian yang disajikan dalam tabulasi silang pada tabel III.9 dapat diketahui bahwa dari 35 responden :

a. Responden yang mempunyai pengetahuan baik dengan sikap ibu positif sebanyak 7 Responden (20\%), sedangkan yang berpengetahuan baik dengan sikap ibu negatif sebanyak 7 responden $(20 \%)$.

b. Responden yang mempunyai pengetahuan cukup dengan sikap ibu positif sebanyak 6 responden (17\%), sedangkan yang berpengetahuan cukup dengan sikap ibu negatif 7 responden $(20 \%)$.

\section{DISKUSI}

\section{Pengetahuan}

Pada bab ini akan di bahas hasil penelitian yang dilakukan pada tanggal 09-21 Mei 2016 Dengan Judul Hubungan Pengetahuan Ibu Hamil Tentang Kenaikan Berat Badan Selama Hamil Dengan Sikap Ibu Dalam Pemenuhan Gizi Seimbang Di Kelurahan Ngronggo Kecamatan Kota, Kota Kediri. c. Responden yang mempunyai pengetahuan kurang dengan sikap ibu positif sebanyak 0 orang $(0 \%)$, sedangkan yang berpengetahuan kurang dengan sikap ibu negatif sebanyak 8 responden $(23 \%)$.

Dari hasil uji statistik chi kuadrat didapatkan $x^{2}$ hitung 18,87 dan bila dibandingkan dengan $x^{2}$ tabel $(\alpha=$ $0,05)$ adalah 5,991 maka $x^{2}$ hitung $>x^{2}$ tabel yaitu $18,87>5,991$ artinya bahwa ada hubungan yang bermakna $\left(\mathrm{H}_{0} \quad\right.$ ditolak $\mathrm{H}_{1} \quad$ diterima) antara pengetahuan ibu hamil tentang kenaikan berat badan selama hamil dengan sikap ibu dalam pemenuhan gizi seimbang di Kelurahan Ngronggo Kecamatan Kota, Kota Kediri.

2. Sikap

Hasil penelitian yang didapatkan dari total 35 responden sebagian besar dari responden yaitu $22(62,86 \%)$ bersikap negatif dalam pemenuhan gizi seimbang.

3. Hubungan Pengetahuan dan Sikap Hasil penelian yang disajikan dalam tabulasi silang menunjukkan bahwa dari total 35 responden sebagian besar dari responden yaitu 14 responden (40\%) mempunyai pengetahuan baik tentang kenaikan 
berat badan selama hamil dan bersikap negatif sebanyak 22 $(62,86 \%)$.

SIMPULAN

Pengetahuan 37 dari $60 \quad(61.67 \%)$ responden yang diteliti memiliki

1. Pengetahuan ibu hamil tentang kenaikan berat badan selama hamil didapatkan 14 responden (40\%) mempunyai pengetahuan baik.

2. Sikap ibu dalam pemenuhan gizi seimbang di Kelurahan Ngronggo Kecamatan Kota, Kota Kediri didapatatkan sebagian besar dari

\section{DAFTAR PUSTAKA}

Almaster Sunita. 2009. Prinsip Dasar Ilmu Gizi. Jakarta: Gramedia Pustaka Utama.

Anggota IKAPI., 2007. Diet Atkins. Jakarta: Media Komputindo.

Arikunto, Suharsimi. 2013. Prosedur Penelitian Suatu Pendekatan Praktik. Jakarta: Rineka Cipta.

Arisman. 2009. Gizi Dalam Daur Kehidupan. Jakarta: EGC

Azwar Saifudin. 2013. Sikap Manusia Teori Dan Pengukurannya. Yogyakarta: Pustaka Pelajar.

Boediman D., 2009. Sehat Bersama Gizi. Jakarta:Sagung Seto.

Budianto Krisna A., 2009. Dasar-dasar Ilmu Gizi. Malang: UMM Pres.

Budiman, Agus Riyanto., 2014. Kapita Selekta Kuesioner Penetahuan Dan Sikap Dalam Penelitian Kesehatan. Jakarta: Salemba Medika.

Goni G. Hubungan Pengetahuan dan Sikap Ibu Hamil dengan Status Gizi Selama Kehamilan di Fakultas Kedokteran Universitas Sam Ratulangi Manado Jurnal Keperawatan Vol. 1 No. 1 Agustus 2013.

Hidayat Alimul A., 2012. Riset Keperawatan Dan Tehnik Penulisan Ilmiah. Jakarta: Salemba Medika. responden yaitu 22 responden $(62,86 \%)$ bersikap negatif.

3. Ada hubungan antara pengetahuan ibu hamil tentang kenaikan berat badan selama hamil dengan sikap ibu dalam pemenuhan gizi seimbang. Berdasarkan hasil uji statistik chi kuadrat didapatkan $x^{2}$ hitung $>x^{2}$ tabel yaitu 18,87>5,991 artinya bahwa ada hubungan yang bermakna $\left(\mathrm{H}_{0} \quad\right.$ ditolak $\quad \mathrm{H}_{1}$ diterima).
Kristiyanasati W., 2010. Gizi Ibu Hamil. Jogjakarta: Nuha Medika.

Kusmiati Y. Wahyuningsih P.H. sujiati. 2009. Perawatan Ibu Hamil (Asuhan Ibu Hamil). Jogjakarta: Fitramaja.

Lailiyana. Noor N. Suryatin. 2010. Gizi Kesehatan Reproduksi. Jakarta: EGC.

Megasari, M. 2015. Panduan Belajar Asuhan Kebidanan. Yogyakarta : Deepublish.

Mubaro, Iqbal. 2011. Promosi Kesehatan untuk Kebidanan. Jakarta : Salemba Medika

Muslimah, R. Tingkat Pengetahuan Ibu Hamil Tentang Gizi Ibu Hamil di Stikes Kusuma Husada Surakarta Jurnal Karya Tulis Ilmiah Juni 2015.

Notoatmodjo Soekidjo. 2010. Metodologi Penelitian Kesehatan. Jakarta: Rineka Cipta.

Nursalam, 2008. Konsep Dan Penerapan Metodologi Penelitian Ilmu Keperawatan. Jakarta: Salemba Medika.

Nyoman D. Bakti B. Ibnu Fajar. 2013. Penilaian Status Gizi. Jakarta: EGC.

Proverawati A. Asfuah S. 2010. Gizi Untuk Kebidanan . Jogjakarta: Nuha Medik.

Purwitasari, Desi., 2009. Gizi Dalam Kesehatan Reproduksi. Yogyakarta: Nuha Medika.

Ramayulis R. Nurlehawati E. Amir E. 2009. Menu Dan Resep Untuk Ibu Hamil. Jakarta: Penebar Plus. 
Restianti Hetti., 2012. Menerapkan Budaya Hidup sehat: Pola Makan Dan Keseimbangan Gizi. Bandung: Puripustaka.

Retno W . Maelani. Hubungan Pengetahuan Ibu Hamil Tentang Kenaikan Berat Badan Selama Hamil Dengan Sikap Ibu Dalam Pemenuhan Gizi Seimbang Di BPS Ny. Lely Kecamatan Boyolongu Kabupaten Tulung Agung Karya Tulis Ilmiah 2014

Rukiyah Yeyeh. Yulianti Lia. 2009. Asuhan Kebidanan 1 (Kehamilan). Jakarta: TIM.

Sari A. Ulfa M. Dawly R. 2015. Asuhan Kebidana Pada Kehamilan Untuk Mahasiswa Kebidanan. Bogor: In Medika.

Setiadi., 2007. Konsep Dan Penelitian Riset Keperawatan. Yogyakarta: Graha Ilmu.

Sugiono., 2012, Statistik Untuk Penelitian. Bandung: Alfabet.

Sujarweni. 2014. Metode Penelitian. Yogyakarta : Pustaka Baru Pres

Sulistiyanti. 2013. Nutrisi Selama Kehamilan. Akbid Medika Surakarta. Infokes Vol. 3 No. 3 November 2013

Wawan Dan Dewi., 2010. Teori Dan Pengukuran Pengetahuan, Sikap, Dan Prilaku Manusia. Yogyakarta:Nuha Medika.

Wibisono Herman., Dewi Kurnia F. 2009. Solusi Sehat Seputar Kehamilan. Jakarta: Agromedia Pustaka.

Wiboworini B., 2009. Gizi Dan Kesehatan. Jakarta: Sunda Kepala Pustaka.

Arachman. 2012. Pemenuhan gizi seimbang [Internet]. Available from : http://marachman.blogspot.co.id [Akses 24 April, 2016].

Suparyanto. 2011. Konsep Dasar Berat Badan Ideal Ibu [Internet]. Available from : http://dr-suparyanto.blogspot.co.id [Akses 24 April, 2016].

Tiyahaning. 2010. Pemenuhan Nutrisi Kehamilan [Internet]. Available from : http://digilib.umpo.ac.id [Akses 23 April, 2016].

Waryana. 2010. Gizi Reproduksi Yogyakarta: Pustaka Rihana [Internet]. Available from : http://perpusnwu.web.id [Akses 6 Mei, 2016].
(2013). Berat Badan Ideal dan Indeks Massa Tubuh [Internet]. Available from : https://www.jevuska.com [Akses 23 April, 2016].

(2013). Dampak Kekurangan Gizi Pada Ibu Hamil_[Internet]. Available from :http://www.seputarduniawanita.com [Akses 24 April, 2016].

.Pengertian Kehamilan [Internet]. Available from :https://id.m.wikipedia [Akses 24 April, 2016].

Novia . (2013). Pentingnya Menjaga Berat Badan Ideal Ketika Hamil. [Internet]. Available from :

http://rapendik.dindik.jatimprov.go.id [Akses 16 April, 2016]. 